\title{
Milk fatty acid composition of Holstein x Gyr dairy cows fed sugarcane-based diets containing citrus pulp supplemented with sunflower oil
}

\section{Perfil de ácidos graxos no leite de vacas Holandês x Gir alimentadas com dietas à base de cana de açúcar, com inclusão de polpa cítrica e suplementadas com óleo de girassol}

\author{
Shirley Motta de Souza ${ }^{1}$; Fernando César Ferraz Lopes ${ }^{2 *}$; Sebastião de Campos \\ Valadares Filho ${ }^{3}$; Marco Antônio Sundfeld da Gama ${ }^{4}$; Luciana Navajas Rennó3; \\ João Paulo Pacheco Rodrigues ${ }^{5}$
}

\begin{abstract}
Sugarcane is a strategic roughage source for milk production in the tropics, and its supplementation with plant oils offers great potential for obtaining milk enriched with beneficial fatty acids, such as oleic (cis-9 C18:1), vaccenic (trans-11 C18:1), and rumenic (cis-9, trans-11 CLA) acids. The aim of this study was to evaluate the milk fatty acid composition of cows fed $60 \%$ chopped sugarcane-based diets containing citrus pulp and $0.0 \%$ (control), $1.5 \%, 3.0 \%$ and $4.5 \%$ sunflower oil on a dry matter basis. Twelve multiparous Holstein $x$ Gyr dairy cows with an average milk production of $17 \pm 5 \mathrm{~kg}$ day $^{-1}$ and $96 \pm 25$ days in milk were allocated in a triplicate $4 \times 4$ Latin square design. There was no effect of dietary treatment on milk production, but sunflower oil supplementation linearly reduced the milk fat content and yield. The milk fat contents of lauric (C12:0), myristic (C14:0), and palmitic (C16:0) fatty acids were linearly reduced with increasing sunflower oil levels. There was a quadratic effect on the milk fat oleic, vaccenic, and rumenic acid contents, while the concentrations of elaidic acid (trans-9 C18:1), trans-10 C18:1 and trans-10, cis-12 CLA linearly increased in response to sunflower oil inclusion. Diet supplementation with sunflower oil linearly reduced both the atherogenicity and thrombogenicity indices and linearly increased the ratio between hypo- and hypercholesterolemic fatty acids in milk fat. The inclusion of up to $4.5 \%$ sunflower oil in $60 \%$ chopped sugarcane-based diets improved the nutritional quality of milk fat from Holstein $\mathrm{x}$ Gyr dairy cows as a result of the increased content of oleic, rumenic and vaccenic acids, which are beneficial to human health, and the concomitant reduction of hypercholesterolemic lauric, myristic and palmitic acids. However, there was an increase in the milk content of trans-10 C18:1 and elaidic acid, which are associated with deleterious effects on cardiovascular health.
\end{abstract}

Key words: Conjugated linoleic acid. Rumenic acid. Saccharum officinarum. Vaccenic acid.

${ }^{1}$ Prof $^{\mathrm{a}}$, Instituto Federal Sul de Minas Gerais, IFSULDEMINAS, Campus Machado, Machado, MG, Brasil. E-mail: motta. shirley@hotmail.com

2 Analista, Empresa Brasileira de Pesquisa Agropecuária, EMBRAPA Gado de Leite, Juiz de Fora, MG, Brasil. E-mail: fernando. lopes@embrapa.br

3 Profs., Departamento de Zootecnia, Universidade Federal de Viçosa, UFV, Viçosa, MG, Brasil. E-mail: scvfilho@ufv.br ; Inrenno@hotmail.com

${ }^{4}$ Pesquisador, EMBRAPA Gado de Leite, Juiz de Fora, MG, Brasil. E-mail: marco.gama@embrapa.br

5 Dr. em Zootecnia, Universidade Federal do Sul e Sudeste do Pará, UNIFESSPA, Instituto de Estudos do Trópico Úmido, Xinguara, PA, Brasil. E-mail: joaopaulo0511@hotmail.com

* Author for correspondence 


\section{Resumo}

A cana de açúcar é um volumoso estratégico em sistemas de produção de leite do Brasil e sua suplementação com óleos vegetais livres apresenta grande potencial para produção de leite enriquecido com os ácidos graxos oleico (C18:1 cis-9), vacênico (C18:1 trans-11) e rumênico (CLA cis-9, trans-11), benéficos à saúde humana. O objetivo deste estudo foi avaliar o perfil de ácidos graxos do leite de vacas alimentadas com $60 \%$ de cana de açúcar e inclusão de polpa cítrica e $0,0 \%$ (controle); $1,5 \% ; 3,0 \%$ e $4,5 \%$ de óleo de girassol na matéria seca da dieta. Foram utilizadas 12 vacas Holandês x Gir com $96 \pm 25$ dias em lactação, produzindo $17 \pm 5 \mathrm{~kg} \mathrm{dia}^{-1}$ de leite, alocadas em três quadrados latinos 4 x 4 . A inclusão do óleo de girassol nas dietas não alterou a produção de leite, mas promoveu redução linear no teor e na produção de gordura. Houve redução linear nos teores dos ácidos graxos láurico (C12:0), mirístico (C14:0) e palmítico (C16:0) no leite. Foi observado efeito quadrático sobre os teores dos ácidos graxos oleico, vacênico e rumênico, e incremento linear nas concentrações dos ácidos graxos elaídico (C18:1 trans-9), C18:1 trans-10 e CLA trans-10, cis-12. Houve redução linear nos índices de aterogenicidade e de trombogenicidade e incremento linear na relação entre ácidos graxos hipo e hipercolesterolêmicos. A inclusão de até $4,5 \%$ de óleo de girassol em dietas baseadas em $60 \%$ de cana de açúcar picada melhorou a qualidade nutricional da gordura do leite de vacas Holandês x Gir, com aumento nos teores dos ácidos graxos oleico, vacênico e rumênico, benéficos à saúde humana, e concomitante redução dos teores dos ácidos graxos hipercolesterolêmicos láurico, mirístico e palmítico. Entretanto, promoveu aumento nos teores dos ácidos graxos elaídico e C18:1 trans-10, associados com efeitos deletérios à saúde cardiovascular.

Palavras-chave: Ácido linoleico conjugado. Ácido rumênico. Ácido vacênico. Saccharum officinarum.

\section{Introduction}

Conjugated linoleic acids (CLA), primarily rumenic acid (cis-9, trans-11 CLA), in milk fat have beneficial effects on human health such as decreasing the risk of cancer and type 2 diabetes and improving the immune system (YANG et al., 2015). Other health-enhancing milk fatty acids (FA) are oleic acid (cis-9 C18:1) and $\alpha$-linolenic acid (cis-9, cis-12, cis-15 C18:3) (LOPES et al., 2015).

The rumenic acid in ruminant products is mostly derived from incomplete ruminal biohydrogenation $(\mathrm{BH})$ of polyunsaturated FA. The rumen outflow of vaccenic acid (trans-11 C18:1) is the precursor of approximately $70 \%$ to $97 \%$ of rumenic acid synthesis in the cow mammary gland (KLIEM; SHINGFIELD, 2016).

Dairy products are the main source of CLA in human nutrition (YANG et al., 2015), and studies integrating ruminant nutrition and milk FA composition are necessary in different situations, including fat supplementation and feed sources.
Sugarcane (Saccharum officinarum L.) is a common forage source in diets for cattle in milk production systems in Brazil (CAMPOS et al., 2017). However, in dairy cows fed sugarcanebased diets without lipidic supplementation, the concentration of rumenic acid in the milk fat is low (MENESES et al., 2015; PIMENTEL et al., 2016). Meneses et al. (2015) supplemented sugarcanebased diets with oleic and linoleic (cis-9, cis-12 C18:2) acids and observed a marked increase (up to $388 \%$ ) in the rumenic acid concentration in the milk fat. However, in the work of Meneses et al. (2015), other FA, such as elaidic acid (trans-9 C18:1) and trans-10 C18:1, which are linked to deleterious effects on cardiovascular health (ALMEIDA et al., 2014; VAHMANI et al., 2017) and thus of significant interest, were not reported.

In this context, a better understanding of feeding strategies that improve human health, especially in regard to dairy products obtained from cows fed sugarcane, is crucial. Both the role of sugarcane in the dairy cow diet and the human demand for 
healthy products increase the relevance of evaluating strategies to increase the content of rumenic acid in milk fat under these circumstances.

Citrus pulp can be used as a high-energy feed in ruminant rations to support growth and lactation with fewer negative effects on rumen fermentation than starch-rich feeds (BAMPIDIS; ROBINSON, 2006) and ground corn. Citrus pulp differs from corn grain in that it has lower concentrations of starch (2.3-7.3\% DM versus 70.98\% DM) and higher concentrations of pectin $(21.0-22.3 \% \mathrm{DM}$ versus $0.41 \%$ DM) (BAMPIDIS; ROBINSON, 2006; VALADARES FILHO et al., 2010). Pectins are degraded very rapidly and extensively in the rumen but, unlike starch, yield little lactate and therefore cause less decrease in rumen $\mathrm{pH}$ (BAMPIDIS; ROBINSON, 2006). As reported by Jenkins and Harvatine (2014), diets containing a high proportion of starch are likely to promote a reduction in ruminal $\mathrm{pH}$, and, when associated with high concentrations of polyunsaturated FA, this can lead to a shift from the trans-11 to the trans-10 pathway of polyunsaturated-FA BH. The shift from the trans-11 to the trans-10 alternative BH pathway promotes a reduction in the availability of vaccenic acid for endogenous synthesis of rumenic acid in the mammary gland and, at the same time, may lead to the production of excessive amounts of trans-10, cis-12 CLA, partially explaining the decrease in milk fat levels (ROY et al., 2006). Thus, in diets containing a high concentration of unsaturated FA, such as those evaluated in the present study, the use of citrus pulp to partially replace ground corn could be a relevant nutritional strategy, considering that in comparison to ground corn, citrus pulp maintains the rumen environment more adequately, favoring the accumulation of vaccenic acid over the formation of trans-10 C18:1 in the BH pathways of unsaturated FA (EIFERT et al., 2006b).

The aim of this study was to evaluate the effect of supplementation with sunflower oil on the milk fatty acid composition of Holstein x Gyr dairy cows fed sugarcane-based diets containing citrus pulp.

\section{Materials and Methods}

The study was conducted at Embrapa Dairy Cattle (Coronel Pacheco, MG, Brazil). All of the experimental procedures with animals were conducted according to Embrapa Dairy Cattle guidelines for animal care and use in research.

Twelve multiparous Holstein x Gyr dairy cows producing $17 \pm 5 \mathrm{~kg}$ day $^{-1}$ of milk, $96 \pm 25$ days in milk, and weighing $500 \pm 51 \mathrm{~kg}$ at the beginning of the experiment were distributed in a three $4 \times 4$ Latin square (LS) design. The cows were homogeneously distributed in each LS based on daily milk yield, days in milk, body weight and lactation order. Each LS period was 16 days in length, with ten and six days for adaptation to the diets and for data collection, respectively.

The experimental treatments were diets based on chopped sugarcane with inclusion (DM basis) of $0.0 \%$ (control), $1.5 \%, 3.0 \%$ and $4.5 \%$ sunflower oil (SO) (Table 1). The diets were formulated at a fixed forage:concentrate ratio of 60:40 (DM basis). The sugarcane variety RB-739735, averaging $18 \pm 4$ brix, was used.

Diets were formulated to be isonitrogenous and to meet the nutritional requirements of cows $500 \mathrm{~kg}$ in body weight producing $17 \mathrm{~kg}$ day $^{-1}$ of milk with $0.3 \mathrm{~kg} \mathrm{day}^{-1}$ of weight gain, in accordance with the NRC (2001).

The cows were collectively lodged in a free-stall equipped with feeders and mineral and drinking troughs. Feed was supplied ad libitum (target 10\% of orts) as a total mixed ration (TMR) once a day (08h00) using a mixer/dispenser vehicle (Data Ranger; American Calan Inc., Northwood, NH, USA). The free-stall was equipped with electronic troughs (American Calan, Inc.) that allowed individual control of feed consumption. The sugarcane was harvested and chopped daily, and the concentrates with sunflower oil were prepared weekly to avoid lipid peroxidation. 
Table 1. Ingredients and chemical composition of the experimental diets on a dry matter (DM) basis.

\begin{tabular}{|c|c|c|c|c|}
\hline \multirow{2}{*}{ Item } & \multicolumn{4}{|c|}{ Sunflower oil levels (\% of diet DM) } \\
\hline & 0.0 & 1.5 & 3.0 & 4.5 \\
\hline \multicolumn{5}{|l|}{ Ingredient composition $(\% \mathrm{DM})$} \\
\hline Sugarcane & 60.0 & 60.0 & 60.0 & 60.0 \\
\hline Citrus pulp & 8.5 & 11.8 & 16.8 & 17.0 \\
\hline Ground corn & 16.5 & 10.9 & 3.9 & 2.0 \\
\hline Soybean meal & 13.3 & 13.8 & 14.25 & 14.4 \\
\hline Sunflower oil & 0.0 & 1.5 & 3.0 & 4.5 \\
\hline Urea + Ammonium sulfate $(9: 1)$ & 1.05 & 1.05 & 1.05 & 1.05 \\
\hline Mineral and vitamin supplement ${ }^{1}$ & 0.96 & 0.98 & 1.03 & 1.06 \\
\hline \multicolumn{5}{|l|}{ Chemical composition (\%DM) } \\
\hline $\mathrm{DM}, \%$ of as fed & 51.2 & 49.6 & 48.3 & 46.9 \\
\hline Organic matter & 93.7 & 91.7 & 89.80 & 88.3 \\
\hline Crude protein $(\mathrm{CP})$ & 12.9 & 12.8 & 12.7 & 12.6 \\
\hline Ether extract (EE) & 1.8 & 3.2 & 4.5 & 5.9 \\
\hline NDF corrected for ash and protein $\left(\mathrm{NDF}_{\mathrm{ap}}\right)$ & 31.1 & 31.2 & 31.5 & 31.3 \\
\hline Nonfibrous carbohydrate corrected for ash and protein ${ }^{2}$ & 47.9 & 44.5 & 41.1 & 38.8 \\
\hline \multicolumn{5}{|l|}{ Fatty acid composition (\% DM) } \\
\hline C16:0 (palmitic acid) & 0.295 & 0.412 & 0.497 & 0.524 \\
\hline C18:0 (stearic acid) & 0.057 & 0.116 & 0.170 & 0.190 \\
\hline cis-9 C18:1 (oleic acid) & 0.421 & 0.793 & 1.066 & 1.214 \\
\hline cis-9, cis-12 C18:2 (linoleic acid) & 0.723 & 1.722 & 2.625 & 3.173 \\
\hline cis-9, cis-12, cis-15 C18:3 ( $\alpha$-linolenic acid) & 0.073 & 0.095 & 0.123 & 0.135 \\
\hline
\end{tabular}

${ }^{1}$ Contained per kg: $255 \mathrm{~g}$ of Ca, $76 \mathrm{~g}$ of P, $30 \mathrm{~g}$ of Mg, $760 \mathrm{mg}$ of F, $20 \mathrm{~g}$ of S, 1,000 mg of Fe, 2,000 mg of Mn, 6,000 mg of Zn, $850 \mathrm{mg}$ of $\mathrm{Cu}, 65 \mathrm{mg}$ of I, $60 \mathrm{mg}$ of $\mathrm{Co}, 20 \mathrm{mg}$ of Se, 220,000 IU of vitamin A, $500 \mathrm{IU}$ of vitamin E and salt (NaCl) was fed ad libitum throughout the study; ${ }^{2}$ Nonfibrous carbohydrate corrected for ash and protein $=100-[(\% \mathrm{CP}-\% \mathrm{CP}$ from urea $+\%$ urea $)+$ $\% \mathrm{NDF}_{\text {ap }}+\% \mathrm{EE}+\% \mathrm{ash}$ ] (DETMANN et al., 2012).

Samples of chopped sugarcane and the four concentrates were collected in each LS period and stored $\left(-20^{\circ} \mathrm{C}\right)$ for chemical analyses. Samples of the individual orts were also collected, and at the end of each LS period, a pooled sample of orts was prepared for each animal and stored at $-20^{\circ} \mathrm{C}$ for later chemical analysis. Fecal samples were collected every $26 \mathrm{~h}$ from $08 \mathrm{~h} 00 \mathrm{~h}$ on day 11 to day 16 of each LS period, pooled per cow, and stored at $-20^{\circ} \mathrm{C}$. At the end of the experiment, the samples of sugarcane, concentrates, orts and feces were thawed, pre-dried $\left(55^{\circ} \mathrm{C}, 72-96 \mathrm{~h}\right)$, milled $(1 \mathrm{~mm})$ and analyzed in the Laboratory of Food Analysis of Embrapa Dairy Cattle (Juiz de Fora, MG, Brazil) for $\mathrm{DM}\left(\right.$ at $\left.105^{\circ} \mathrm{C}\right)$, crude protein $(\mathrm{CP})$, ether extract (EE), mineral matter (MM), acid detergent fiber (ADF), neutral detergent fiber corrected for ash and protein $\left(\mathrm{NDF}_{\mathrm{ap}}\right)$ and lignin content according to Detmann et al. (2012).

Samples of chopped sugarcane collected in each LS period and samples of each ingredient of the concentrates (citrus pulp, ground corn and soybean meal) were lyophilized and analyzed for FA composition as described by Ribeiro et al. (2014). A sample of SO was also collected and stored for FA composition analysis. This analysis was performed in the Laboratory of Chromatography of Embrapa Dairy Cattle (Juiz de Fora, MG, Brazil) using a 
6890N chromatograph (Agilent Technologies, Santa Clara, CA, USA) with a capillary column (25 m x $0.20 \mathrm{~m} \times 0.33 \mu \mathrm{m}$ ) of polyethylene glycol (HP-FFAP, Agilent Technologies, Santa Clara, CA, USA) and a flame ionization detector. The FA content $\left(\mathrm{g} \mathrm{kg}^{-1} \mathrm{DM}\right)$ was quantified by the addition of C19:0 internal standard.

To estimate digestibility, the indigestible neutral detergent fiber (iNDF) was used as an internal marker. The iNDF was quantified via $264 \mathrm{~h}$ of ruminal in situ incubation using Ankom filter bags F57 (ANKOM Technology, Macedon, NY, USA).

Cows were milked twice daily (06h00 and 14h00), and the milk yield was recorded throughout the collection period (days 11 to 16 of each LS period). Milk samples were collected in both milking sessions and pooled daily proportionally to production in each sampling $(2 / 3$ at morning milking $+1 / 3$ at afternoon milking). Concentrations of milk lactose, fat and protein were performed by medium infrared spectrometry (Bentley 2300; Bentley Instruments, Inc., Chaska, MN, USA) at the Milk Quality Laboratory of Embrapa Dairy Cattle (Juiz de Fora, MG, Brazil).

Milk samples for FA analyses were collected on day 16 of each LS period. The FA composition was analyzed by gas chromatography according to the procedures of Ribeiro et al. (2018).

The nutritional quality of milk fat was evaluated by the atherogenicity (AI) and thrombogenicity (TI) indices, by the omega-6 and omega-3 FA ratio ( $\omega-6 / \omega-3$ FA ratio) and by the hypo- and hypercholesterolemic FA ratio (h/H FA ratio), calculated according to Ribeiro et al. (2018).

Blood samples were collected on day 16 of each LS period via coccygeal venipuncture, using test tubes (Vacutainer; Becton-Dickinson, Rutherford, NJ, USA) containing the anticoagulant EDTA. The samples were centrifuged immediately at 3,000 x $g$ for $15 \mathrm{~min}$, and plasma $(2.0 \mathrm{~mL})$ was stored in Eppendorf tubes at $-20^{\circ} \mathrm{C}$ until analysis. Plasma concentrations of non-esterified FA (NEFA), glucose, cholesterol, and triglycerides were estimated using commercial kits as described by Rodrigues et al. (2017).

The results were analyzed by mixed models using the MIXED procedure of SAS version 9.0 (SAS Institute, Inc., Cary, NC, USA). The SO concentration in the diet was considered as a fixed effect, and LS, cow within LS and LS period were considered as random effects. The linear and quadratic effects of SO concentrations were analyzed by contrasts. Regression equations between specific variables were adjusted by the REG procedure, and Pearson correlations were obtained by the CORR procedure of SAS. Effects were considered significant when $\mathrm{P} \leq 0.05$.

\section{Results and Discussion}

There was no effect $(\mathrm{P}>0.05)$ of sunflower oil (SO) supplementation on DM, OM or TDN intake (Table 2). Since the diets were isoproteic and isofibrous (Table 1) with similar DM intake, there was also no effect $(\mathrm{P}>0.05)$ of $\mathrm{SO}$ supplementation on $\mathrm{CP}$ or $\mathrm{NDF}_{\text {ap }}$ intake (Table 2).

To avoid a decrease in DM intake, the NRC (2001) recommends formulating rations for dairy cows with a maximum of 6-7\% EE (DM basis). In the present study, the EE concentrations did not reach this value (Table 1). However, it should be noted that free vegetable oils are rapidly released in the rumen and have subsequent potential deleterious effects on the resident microbiota, fiber digestion and DM intake. It is likely that the inclusion of SO, which was previously mixed with the concentrate, contributed to avoiding decreased DM intake (NRC, 2001). According to Jenkins (1993), the deposition of a layer of oil on the forage particles can impair both the adhesion of fibrolytic microbiota and the activity of the enzymes involved in cellulose hydrolysis, negatively affecting the digestion of the fibrous fraction of the diet and therefore the DM intake. 
As expected, the substitution of ground corn and citrus pulp rich in nonfibrous carbohydrate (NFC) by $\mathrm{SO}$ rich in fat resulted in a linear increase in $\mathrm{EE}$ intake $(\mathrm{P}<0.0001)$ and a linear decrease $(\mathrm{P}=0.0006)$ in NFC corrected for ash and protein $\left(\mathrm{NFC}_{\mathrm{ap}}\right)$ intake (Table 2).

Table 2. Intake and apparent digestibility of nutrients in Holstein x Gyr cows fed sugarcane-based diets containing increasing levels of sunflower oil (SO).

\begin{tabular}{|c|c|c|c|c|c|c|c|}
\hline \multirow{2}{*}{ Item } & \multicolumn{4}{|c|}{ SO levels (\% of diet DM) } & \multirow{2}{*}{$\begin{array}{l}\text { Standard error } \\
\text { of the mean }\end{array}$} & \multicolumn{2}{|c|}{ P-value } \\
\hline & 0.0 & 1.5 & 3.0 & 4.5 & & Linear & Quadratic \\
\hline \multicolumn{8}{|c|}{ Nutrient intake $\left(\mathrm{kg}\right.$ day $\left.^{-1}\right)$} \\
\hline Dry matter (DM) & 15.8 & 15.9 & 16.1 & 14.8 & 0.7535 & 0.2833 & 0.1826 \\
\hline Organic matter & 15.5 & 15.1 & 15.1 & 14.1 & 0.7683 & 0.0810 & 0.6234 \\
\hline Crude protein $(\mathrm{CP})$ & 2.01 & 1.96 & 1.96 & 1.83 & 0.0820 & 0.0767 & 0.6018 \\
\hline Ether extract (EE) & 0.29 & 0.51 & 0.74 & 0.91 & 0.0308 & $<0.0001$ & 0.3253 \\
\hline $\mathrm{NDF}_{\mathrm{ap}}{ }^{1}$ & 5.68 & 5.63 & 5.51 & 5.29 & 0.2327 & 0.1689 & 0.6797 \\
\hline $\mathrm{NFC}_{\text {ap }}{ }^{2}$ & 7.87 & 7.29 & 7.21 & 6.42 & 0.5402 & 0.0006 & 0.6831 \\
\hline $\mathrm{TDN}^{3}$ & 11.8 & 11.8 & 12.2 & 11.7 & 0.8412 & 0.9698 & 0.5460 \\
\hline \multicolumn{8}{|c|}{ Nutrient intake (kg $100 \mathrm{~kg}^{-1}$ of body weight) } \\
\hline $\mathrm{DM}$ & 3.07 & 3.08 & 3.12 & 2.87 & 0.1460 & 0.2189 & 0.2136 \\
\hline $\mathrm{NDF}_{\mathrm{ap}}{ }^{1}$ & 1.09 & 1.08 & 1.08 & 1.02 & 0.0449 & 0.2686 & 0.4771 \\
\hline \multicolumn{8}{|c|}{ Apparent nutrient digestibility (\%) } \\
\hline $\mathrm{DM}$ & 71.0 & 71.1 & 69.6 & 71.5 & 2.2118 & 0.9974 & 0.2706 \\
\hline $\mathrm{CP}$ & 65.6 & 69.2 & 71.0 & 71.0 & 1.8636 & $<0.0001$ & 0.0427 \\
\hline $\mathrm{EE}$ & 84.4 & 91.9 & 94.1 & 94.4 & 1.9474 & $<0.0001$ & 0.0053 \\
\hline $\mathrm{NDF}_{\text {ap }}^{1}$ & 44.3 & 44.5 & 45.5 & 46.6 & 1.0010 & 0.0576 & 0.4020 \\
\hline $\mathrm{NFC}_{\mathrm{ap}}{ }^{2}$ & 94.1 & 94.4 & 93.7 & 93.6 & 0.5265 & 0.1202 & 0.5616 \\
\hline $\mathrm{TDN}^{3}$ & 72.6 & 75.0 & 77.1 & 78.7 & 2.4819 & $<0.0001$ & 0.6137 \\
\hline
\end{tabular}

${ }^{1} \mathrm{NDF}_{\mathrm{ap}}=$ neutral detergent fiber corrected for ash and protein; ${ }^{2} \mathrm{NFC}_{\mathrm{ap}}$ (nonfibrous carbohydrate corrected for ash and protein) $=100$ $-\left[(\% \mathrm{CP}-\% \mathrm{CP}\right.$ from urea $+\%$ urea $\left.)+\% \mathrm{NDF}_{\text {ap }}+\% \mathrm{EE}+\% \mathrm{ash}\right]\left(\mathrm{DETMANN}\right.$ et al., 2012); ${ }^{3} \mathrm{TDN}$ ( Total digestible nutrients $)=\mathrm{DCP}$ $+\mathrm{DNDF}_{\text {ap }}+\mathrm{DNFC}_{\text {ap }}+2.25 * \mathrm{DEE}\left(\right.$ WEISS, 1999), where DCP $=$ digestible CP; $\mathrm{NDF}_{\text {ap }}=\operatorname{digestible~} \mathrm{NDF}_{\mathrm{ap}} ; \mathrm{DNFC}_{\mathrm{ap}}=$ digestible $^{\mathrm{a}}$ $\mathrm{NFC}_{\mathrm{ap}}$; and $\mathrm{DEE}=$ digestible $\mathrm{EE}$.

The increase in TDN $(\mathrm{P}<0.0001)$ with increasing SO levels (Table 2) is clearly a consequence of the substitution of carbohydrate sources by fat, which has a 2.25-fold greater energy concentration (WEISS, 1999). In addition, the digestibility of CP and EE increased with SO supplementation (Table 2). In the present study, the inclusion of SO in the diets was accompanied by the partial substitution of citrus pulp for ground corn (Table 1). This strategy was adopted since citrus pulp, in comparison to ground corn, maintains the ruminal environment more adequately, favoring the accumulation of vaccenic acid over the formation of trans-10 C18:1 in the BH pathways of unsaturated FA (EIFERT et al., 2006b). In addition, in previous studies, the partial (ASSIS et al., 2004) or total (ASSIS et al., 2004; EIFERT et al., 2006a) replacement of ground corn with citrus pulp did not change $(\mathrm{P}>0.05) \mathrm{DM}$ or TDN intake, milk yield (corrected or not-corrected for fat), or the fat or protein content of the milk obtained from cows producing, on average, 20.5 to $23.5 \mathrm{~kg}$ day $^{-1}$ and fed diets based on sorghum silage or corn silage. 
On the other hand, using diets based on corn silage and sunflower silage, Leite et al. (2017) reported lower DM intake when citrus pulp was included as a replacement for ground corn. These authors also observed that cows receiving citrus pulp spent more time ingesting, ruminating and chewing (per $\mathrm{kg}$ of DM or NDF) than those that received ground corn. It is therefore postulated that the resistance of the foodstuffs to breakdown during mastication might have lowered the intake rate, leading to lower DM intake (CARMO et al., 2015). Leite et al. (2017) did not observe an effect of the inclusion of citrus pulp or ground corn on the nutrient digestibilities of the diets. In another study of lactating cows, Carmo et al. (2015) reported a linear increase in the DM intake of corn silage-based diets in which ground corn was included as a substitute for citrus pulp. According to these authors, the observed reduction in DM intake in animals fed diets containing citrus pulp may be associated with the higher water-holding capacity of pectin, which increases the rumen digesta volume and contributes to intake limitation due to rumen distention. In the present study, however, there was no reduction in the DM intake of the cows fed the experimental diets.

Despite the differences in the levels of the majority of FA in the diets (Table 1), the quadratic effects $(\mathrm{P}<0.05)$ of $\mathrm{SO}$ supplementation on their intakes (Table 3) were mainly modulated by the observed patterns of DM intake associated with the diets (Table 2). Independent of the diet and because it was the major FA in all dietary ingredients (Table 4) and diets (Table 1), linoleic acid was the main FA consumed by cows. Relative to the control treatment, SO supplementation resulted in increases in linoleic acid intake of $145 \%, 278 \%$ and $320 \%$ in the diets containing $1.5 \%, 3.0 \%$ and $4.5 \% \mathrm{SO}$, respectively (Table 3). The second FA most consumed by cows, oleic acid (Table 3), was present in high concentrations in all dietary ingredients (Table 4). These two FA, together with $\alpha$-linolenic acid, are substrates for the formation of vaccenic acid in the rumen by partial BH reactions (SHINGFIELD et al., 2010). Since none of the ingredients of the concentrate is an important source of $\alpha$-linolenic acid (Table 4), the intake of $\alpha$-linolenic acid in the diets was low (Table 3). In addition, relative to well-managed tropical grasses, chopped sugarcane, which accounted for $60 \%$ of the DM in the diets (Table 1), has a lower $\alpha$-linolenic acid content, although the concentrations of oleic and linoleic acids in chopped sugarcane are, in general, higher (LOPES et al., 2015).

Table 3. Fatty acid (FA) intake in Holstein $\mathrm{x}$ Gyr cows fed sugarcane-based diets containing increasing levels of sunflower oil (SO).

\begin{tabular}{|c|c|c|c|c|c|c|c|}
\hline \multirow{2}{*}{ FA $\left(\mathrm{g} \mathrm{day}^{-1}\right)$} & \multicolumn{4}{|c|}{ SO levels (\% of diet DM) } & \multirow{2}{*}{$\begin{array}{l}\text { Standard error of } \\
\text { the mean }\end{array}$} & \multicolumn{2}{|c|}{ P-value } \\
\hline & 0.0 & 1.5 & 3.0 & 4.5 & & Linear & Quadratic \\
\hline Palmitic acid & 46.4 & 65.7 & 80.1 & 77.6 & 3.2967 & $<0.0001$ & 0.0003 \\
\hline Stearic acid & 8.83 & 18.5 & 27.4 & 28.1 & 1.1156 & $<0.0001$ & $<0.0001$ \\
\hline Oleic acid & 65.8 & 126.5 & 171.9 & 179.8 & 7.2210 & $<0.0001$ & $<0.0001$ \\
\hline Linoleic acid & 112.0 & 274.8 & 423.3 & 470.3 & 18.3881 & $<0.0001$ & 0.0003 \\
\hline$\alpha$-Linolenic acid & 11.5 & 15.1 & 19.9 & 19.9 & 0.9250 & $<0.0001$ & 0.0111 \\
\hline
\end{tabular}


Table 4. Fatty acid (FA) composition of the ingredients used in the concentrates.

\begin{tabular}{lccccc}
\hline Fatty acid $\left(\mathrm{g} 100 \mathrm{~g}^{-1} \mathrm{FA}\right)$ & Sugarcane $^{1}$ & Soybean meal & Ground corn & Citrus pulp & Sunflower oil \\
\hline Palmitic acid & $24.04 \pm 5.27$ & 18.86 & 17.07 & 29.80 & 7.54 \\
Stearic acid & $3.90 \pm 1.04$ & 5.14 & 3.95 & 5.95 & 3.56 \\
Oleic acid & $11.35 \pm 3.28$ & 17.21 & 35.69 & 20.30 & 22.07 \\
Linoleic acid & $28.55 \pm 4.65$ & 49.93 & 40.03 & 31.73 & 59.94 \\
$\alpha$-Linolenic acid & $9.48 \pm 3.17$ & 5.61 & 0.94 & 5.47 & 1.36 \\
\hline
\end{tabular}

${ }^{1}$ Mean \pm standard deviation ( $n=4$ samples $)$.

In Holstein cows fed 40\% sugarcane-based diets supplemented with $0 \%, 1.57 \%, 4.43 \%$ and $7.34 \%$ soybean oil, Rodrigues et al. (2017) reported a linear reduction $(\mathrm{P}<0.05)$ in the fat and lactose content of milk as well as a reduction in fat and protein production. These authors observed a quadratic effect on milk protein content $(\mathrm{P}=0.06)$ and on lactose and energy-corrected milk yield $(\mathrm{P}<0.05)$ in response to soybean oil supplementation. It is possible that the differences in the patterns of milk production and composition observed in the present study in relation to those reported by Rodrigues et al. (2017) may be associated with the higher inclusion of vegetable oil (7.34\% soybean oil) in their study as well as with the different proportions of sugarcane in the diets evaluated in the two studies.
According to Carmo et al. (2015), starch digestion tends to produce more glucogenic nutrients (propionate) than does pectin; because the amount of lactose produced greatly determines milk yield, the availability of glucogenic precursors from the diet is an important factor that may affect milk production. In a companion paper in which the ruminal metabolism of cows fed chopped sugarcanebased diets containing citrus pulp supplemented with the same dietary levels of SO was studied, Souza (2011) observed no effect of the treatments on the amount of propionate in the rumen. Thus, the lack of effect of the treatments on lactose content in the present study may be a reflection of this and may partially contribute to the observed similarity in milk production (Table 5).

Table 5. Milk production and composition of Holstein x Gyr cows fed sugarcane-based diets containing increasing levels of sunflower oil (SO).

\begin{tabular}{|c|c|c|c|c|c|c|c|}
\hline \multirow{2}{*}{ Item } & \multicolumn{4}{|c|}{ SO levels (\% of diet DM) } & \multirow{2}{*}{$\begin{array}{c}\text { Standard error of } \\
\text { the mean }\end{array}$} & \multicolumn{2}{|c|}{$\mathrm{P}$-value } \\
\hline & 0.0 & 1.5 & 3.0 & 4.5 & & Linear & Quadratic \\
\hline \multicolumn{8}{|l|}{ Yield } \\
\hline Milk yield $\left(\mathrm{kg} \mathrm{day}^{-1}\right)$ & 18.0 & 18.3 & 17.5 & 19.2 & 1.238 & 0.2185 & 0.1647 \\
\hline FCM $\left(\mathrm{kg} \mathrm{day}^{-1}\right)^{1}$ & 16.5 & 16.5 & 14.6 & 15.4 & 1.211 & 0.0467 & 0.4418 \\
\hline Fat $\left(\right.$ g day $\left.^{-1}\right)$ & 621.3 & 610.3 & 507.8 & 516.2 & 53.919 & 0.0032 & 0.7403 \\
\hline Protein $\left(\mathrm{g}\right.$ day $\left.^{-1}\right)$ & 546.2 & 514.0 & 513.4 & 557.4 & 45.410 & 0.9358 & 0.0257 \\
\hline Lactose $\left(\mathrm{g}\right.$ day $\left.^{-1}\right)$ & 775.7 & 800.3 & 769.8 & 818.3 & 59.013 & 0.6020 & 0.7300 \\
\hline Total solids $\left(\mathrm{g}\right.$ day $\left.^{-1}\right)$ & $2,122.5$ & $2,087.5$ & $1,945.0$ & $2,054.4$ & 162.880 & 0.2251 & 0.2575 \\
\hline \multicolumn{8}{|l|}{ Composition (\%) } \\
\hline Fat & 3.46 & 3.30 & 2.90 & 2.68 & 0.205 & 0.0002 & 0.8083 \\
\hline Protein & 3.04 & 2.80 & 2.94 & 2.90 & 0.110 & 0.3176 & 0.0872 \\
\hline Lactose & 4.31 & 4.36 & 4.40 & 4.26 & 0.086 & 0.6298 & 0.0958 \\
\hline Total solids & 11.79 & 11.35 & 11.10 & 10.68 & 0.335 & 0.0001 & 0.9446 \\
\hline
\end{tabular}

${ }^{1}$ Fat-corrected milk $($ NRC, 2001$)=(0.4 *$ MilkProd $)+15 *($ MilkFat*/100 $) *$ MilkProd. 
Positive correlations between milk yield versus $\mathrm{DM}$ intake $(\mathrm{r}=0.33 ; \mathrm{P}=0.0290), \mathrm{OM}(\mathrm{r}=0.38$; $\mathrm{P}=0.0111)$ and $\operatorname{TDN}(\mathrm{r}=0.43, \mathrm{P}=0.0037)$ were observed, indicating that the absence of an effect $(\mathrm{P}>0.05)$ of $\mathrm{SO}$ supplementation on milk production (Table 5) may be a reflection of the similarity $(\mathrm{P}>0.05)$ of the diets with respect to the intake of these fractions (Table 2). The linear reduction $(\mathrm{P}=0.0002)$ in milk fat content (Table 5) can be explained by the linear increase $(\mathrm{P}<0.0001)$ in the milk content of trans-10, cis-12 CLA, trans-9, cis-11 CLA (Table 6). These FA (and possibly others such as trans-10 C18:1) are associated with inhibition of lipogenesis in the cow mammary gland (SHINGFIELD et al., 2010; BERNARD et al., 2018), promoting a decrease in the level of milk fat. This is corroborated by the regressions obtained between milk fat content (\%) versus milk concentrations (g $\left.100 \mathrm{~g}^{-1} \mathrm{FA}\right)$ of trans-10, cis-12 $\operatorname{CLA}\left(\hat{\mathrm{y}}=-7.9101 * \mathrm{x}+3.50796 ; \mathrm{r}^{2}=0.46 ; \mathrm{P}<0.0001\right)$ and trans-9, cis-11 CLA $(\hat{\mathrm{y}}=-6.56848 * \mathrm{x}+3.50094$; $\left.\mathrm{r}^{2}=0.12 ; \mathrm{P}=0.00123\right)$. However, the higher slope coefficient in the regression between fat content and the concentration of trans-10, cis-12 CLA in milk indicates the greater relevance of this isomer to the inhibition of mammary lipogenesis (ROY et al., 2006).

Table 6. Fatty acid (FA) composition in milk from Holstein x Gyr cows fed sugarcane-based diets containing increasing levels of sunflower oil (SO).

\begin{tabular}{|c|c|c|c|c|c|c|c|}
\hline \multirow{2}{*}{$\mathrm{FA}\left(\mathrm{g} 100 \mathrm{~g}^{-1} \mathrm{FA}\right)$} & \multicolumn{4}{|c|}{ SO levels ( $\%$ of diet DM) } & \multirow{2}{*}{$\begin{array}{l}\text { Standard error } \\
\text { of the mean }\end{array}$} & \multicolumn{2}{|c|}{ P-value } \\
\hline & 0.0 & 1.5 & 3.0 & 4.5 & & Linear & Quadratic \\
\hline \multicolumn{8}{|l|}{ Linear even-chain saturated FA } \\
\hline$\Sigma 4 \leq \mathrm{C} \leq 10$ & 10.98 & 10.09 & 7.64 & 5.81 & 0.544 & $<0.0001$ & 0.2599 \\
\hline $\mathrm{C} 12: 0$ & 4.02 & 3.07 & 2.19 & 1.72 & 0.189 & $<0.0001$ & 0.0919 \\
\hline C14:0 & 12.25 & 10.76 & 8.73 & 7.27 & 0.314 & $<0.0001$ & 0.9541 \\
\hline C16:0 & 34.38 & 26.90 & 22.50 & 20.01 & 1.031 & $<0.0001$ & 0.0679 \\
\hline$\Sigma 12 \leq \mathrm{C} \leq 16$ & 50.66 & 40.72 & 33.42 & 29.01 & 1.434 & $<0.0001$ & 0.2135 \\
\hline$\Sigma 4 \leq \mathrm{C} \leq 16$ & 61.60 & 50.83 & 41.01 & 34.87 & 1.738 & $<0.0001$ & 0.5813 \\
\hline C18:0 & 7.91 & 11.85 & 12.99 & 13.50 & 0.808 & $<0.0001$ & 0.0004 \\
\hline C20:0 & 0.11 & 0.13 & 0.13 & 0.14 & 0.008 & 0.0003 & 0.3244 \\
\hline $\mathrm{C} 22: 0$ & 0.040 & 0.059 & 0.062 & 0.080 & 0.007 & $<0.0001$ & 0.9936 \\
\hline $\mathrm{C} 24: 0$ & 0.034 & 0.043 & 0.034 & 0.035 & 0.006 & 0.7757 & 0.4923 \\
\hline$\Sigma \geq 18 \mathrm{C}$ & 8.10 & 12.08 & 13.22 & 13.76 & 0.823 & $<0.0001$ & 0.0005 \\
\hline \multicolumn{8}{|c|}{ Odd- and branched-chain FA (OBCFA) } \\
\hline $\mathrm{C} 11: 0$ & 0.48 & 0.33 & 0.19 & 0.12 & 0.039 & $<0.0001$ & 0.1252 \\
\hline C13:0 & 0.147 & 0.099 & 0.069 & 0.054 & 0.012 & $<0.0001$ & 0.1505 \\
\hline iso $\mathrm{C} 15: 0$ & 0.25 & 0.21 & 0.17 & 0.14 & 0.012 & $<0.0001$ & 0.9336 \\
\hline anteiso $\mathrm{C} 15: 0$ & 0.43 & 0.37 & 0.35 & 0.30 & 0.023 & $<0.0001$ & 0.7463 \\
\hline $\mathrm{C} 15: 0$ & 1.63 & 1.13 & 0.92 & 0.84 & 0.079 & $<0.0001$ & 0.0155 \\
\hline $\mathrm{C} 17: 0$ & 0.51 & 0.43 & 0.45 & 0.42 & 0.030 & 0.0052 & 0.1288 \\
\hline cis-9 C17:1 & 0.21 & 0.15 & 0.15 & 0.14 & 0.009 & $<0.0001$ & 0.0007 \\
\hline $\mathrm{C} 21: 0$ & 0.023 & 0.035 & 0.051 & 0.079 & 0.009 & $<0.0001$ & 0.3569 \\
\hline$\Sigma$ odd linear-chain FA & 3.01 & 2.17 & 1.83 & 1.66 & 0.1195 & $<0.0001$ & 0.0131 \\
\hline$\Sigma$ OBCFA & 3.69 & 2.75 & 2.35 & 2.09 & 0.1179 & $<0.0001$ & 0.0118 \\
\hline \multicolumn{8}{|l|}{ cis-chain monounsaturated FA } \\
\hline cis-9 C14:1 & 1.13 & 0.82 & 0.61 & 0.54 & 0.1395 & $<0.0001$ & 0.0051 \\
\hline cis-9 C16:1 & 1.61 & 1.04 & 0.83 & 0.83 & 0.1534 & $<0.0001$ & $<0.0001$ \\
\hline cis-9 C18:1 & 14.76 & 18.35 & 19.80 & 20.56 & 1.1782 & $<0.0001$ & 0.0422 \\
\hline
\end{tabular}




\begin{tabular}{|c|c|c|c|c|c|c|c|}
\hline cis-11 C18:1 & 0.95 & 1.13 & 1.29 & 1.33 & 0.0743 & $<0.0001$ & 0.1511 \\
\hline cis-12 C18:1 & 0.30 & 0.57 & 0.73 & 0.69 & 0.0461 & $<0.0001$ & 0.0013 \\
\hline cis-13 C18:1 & 0.050 & 0.072 & 0.103 & 0.165 & 0.0132 & $<0.0001$ & 0.1600 \\
\hline cis-11 C20:1 & 0.039 & 0.046 & 0.061 & 0.071 & 0.0034 & $<0.0001$ & 0.5347 \\
\hline \multicolumn{8}{|l|}{ trans-C18:1 FA } \\
\hline trans-4 C18:1 & 0.015 & 0.028 & 0.042 & 0.058 & 0.0048 & $<0.0001$ & 0.7743 \\
\hline trans-5 C18:1 & 0.015 & 0.026 & 0.045 & 0.062 & 0.0076 & $<0.0001$ & 0.6371 \\
\hline trans-6-8 C18:1 & 0.10 & 0.26 & 0.49 & 0.68 & 0.0607 & $<0.0001$ & 0.7243 \\
\hline trans-9 C18:1 & 0.17 & 0.32 & 0.48 & 0.62 & 0.0470 & $<0.0001$ & 0.4207 \\
\hline trans-10 C18:1 & 0.27 & 0.57 & 1.66 & 4.14 & 0.7118 & $<0.0001$ & 0.0579 \\
\hline trans-11 C18:1 & 1.14 & 3.35 & 6.40 & 7.56 & 0.5857 & $<0.0001$ & 0.0068 \\
\hline trans-12 C18:1 & 0.18 & 0.53 & 0.91 & 1.20 & 0.0543 & $<0.0001$ & 0.5808 \\
\hline trans-13-14 C18:1 & 0.26 & 0.62 & 0.99 & 1.11 & 0.0825 & $<0.0001$ & 0.0319 \\
\hline trans-16 C18:1 & 0.17 & 0.32 & 0.53 & 0.49 & 0.0344 & $<0.0001$ & 0.0093 \\
\hline$\sum$ trans-C18:1 & 2.37 & 6.03 & 11.57 & 15.90 & 0.8087 & $<0.0001$ & 0.1405 \\
\hline \multicolumn{8}{|c|}{ Conjugated (CLA) and non-conjugated isomers of linoleic acid } \\
\hline cis-9, trans-12 C18:2 & 0.07 & 0.15 & 0.18 & 0.18 & 0.0172 & $<0.0001$ & 0.0120 \\
\hline cis-9, trans-11 CLA & 0.56 & 1.46 & 2.41 & 2.77 & 0.3515 & $<0.0001$ & 0.0090 \\
\hline trans-9, cis-11 CLA & 0.025 & 0.049 & 0.073 & 0.102 & 0.0080 & $<0.0001$ & 0.7115 \\
\hline trans-10, cis-12 CLA & 0.013 & 0.029 & 0.064 & 0.105 & 0.0161 & $<0.0001$ & 0.3366 \\
\hline \multicolumn{8}{|l|}{ Long-chain polyunsaturated FA } \\
\hline cis-9, cis-12 C18:2 ( $\omega-6)$ & 1.87 & 1.98 & 2.07 & 2.01 & 0.1162 & 0.3093 & 0.4336 \\
\hline cis-6, cis-9, cis-12 C18:3 ( $\omega-6)$ & 0.092 & 0.091 & 0.085 & 0.092 & 0.0070 & 0.8067 & 0.4118 \\
\hline cis-9, cis-12, cis-15 C18:3 ( $\omega-3)$ & 0.14 & 0.12 & 0.13 & 0.12 & 0.0125 & 0.2408 & 0.6290 \\
\hline 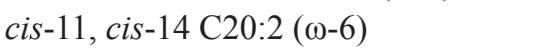 & 0.029 & 0.020 & 0.016 & 0.023 & 0.0071 & 0.4144 & 0.1670 \\
\hline cis-8, cis-11, cis-14 C20:3 ( $\omega-6)$ & 0.077 & 0.071 & 0.052 & 0.053 & 0.0080 & 0.0053 & 0.6175 \\
\hline cis -5, cis- 8, cis- 11, cis-14 C20:4 ( $\omega-6)$ & 0.16 & 0.11 & 0.10 & 0.08 & 0.0103 & $<0.0001$ & 0.1014 \\
\hline$\sum$ cis $\omega-6$ FA & 2.22 & 2.27 & 2.31 & 2.25 & 0.1254 & 0.7945 & 0.6222 \\
\hline \multicolumn{8}{|l|}{ Ratios between FA } \\
\hline C18:0/trans-11 C18:1 & 8.26 & 3.84 & 2.11 & 2.00 & 0.4706 & $<0.0001$ & 0.0003 \\
\hline C18:0/trans-10 C18:1 & 34.26 & 21.11 & 12.60 & 6.97 & 3.0662 & $<0.0001$ & 0.0288 \\
\hline C18:0/trans-9 C18:1 & 48.41 & 38.80 & 28.23 & 23.18 & 2.8488 & $<0.0001$ & 0.2637 \\
\hline trans-11 C18:1/trans-10 C18:1 & 4.38 & 5.62 & 6.28 & 5.17 & 1.0474 & 0.3386 & 0.1016 \\
\hline
\end{tabular}

Abbreviations: $\Sigma 4 \leq \mathrm{C} \leq 10=\mathrm{C} 4: 0+\mathrm{C} 6: 0+\mathrm{C} 8: 0+\mathrm{C} 10: 0 ; \Sigma 12 \leq \mathrm{C} \leq 16=\mathrm{C} 12: 0+\mathrm{C} 14: 0+\mathrm{C} 16: 0 ; \Sigma 4 \leq \mathrm{C} \leq 16=\mathrm{C} 4: 0+\mathrm{C} 6: 0+\mathrm{C} 8: 0$ $+\mathrm{C} 10: 0+\mathrm{C} 12: 0+\mathrm{C} 14: 0+\mathrm{C} 16: 0 ; \Sigma \mathrm{C} \geq 18=\mathrm{C} 18: 0+\mathrm{C} 20: 0+\mathrm{C} 22: 0+\mathrm{C} 24: 0 ; \Sigma$ odd- linear-chain FA $=\mathrm{C} 11: 0+\mathrm{C} 13: 0+\mathrm{C} 15: 0+$ $\mathrm{C} 17: 0+$ cis-9 $\mathrm{C} 17: 1+\mathrm{C} 21: 0 ; \Sigma$ OBCFA $=$ iso $\mathrm{C} 15: 0+$ anteiso $\mathrm{C} 15: 0+\Sigma$ odd- linear-chain $\mathrm{FA} ; \Sigma$ trans-C18:1 FA $=$ trans-4 C18:1 + trans-5 C18:1 + trans-6-8 C18:1 + trans-9 C18:1 + trans-10 C18:1 + trans-11 C18:1 + trans-12 C18:1 + trans-13-14 C18:1 + trans-16 C18:1.

The mechanisms responsible for the inhibitory effects of trans-10, cis-12 CLA and trans-9, cis11 CLA or any other FA (e.g., trans-10 C18:1) on milk fat synthesis have not been clearly elucidated. In general, these mechanisms are associated with a dramatic decrease in the expression of the main lipogenic genes that encode transcription factors and key enzymes of de novo FA synthesis in the mammary gland (KADEGOWDA et al., 2009;
SHINGFIELD et al., 2010; BERNARD et al., 2018). It should be noted that de novo FA synthesis is responsible for $100 \%$ of the linear even-chain saturated FAC4:0 to $\mathrm{C} 12: 0$, approximately $95 \%$ of the myristic acid (C14:0), and 50\% of the palmitic acid (C16:0) secreted in milk (KLIEM; SHINGFIELD, 2016). The high negative correlations between milk concentrations of trans-10, cis-12 CLA and trans-9, cis-11 CLA versus C4:0 to C16:0 FA ( $\mathrm{r}=$ 
-0.58 to $-0.81 ; \mathrm{P}<0.0001)$ indicate that these CLA isomers in fact inhibit lipogenesis in the mammary gland by reduction of de novo FA synthesis (BERNARD et al., 2018). Thus, in response to SO supplementation, the strong reduction $(\mathrm{P}<0.0001)$ in the milk content of de novo-synthesized FA C4:0 to C16:0 (Table 6), the sum of the levels of which was positively correlated with milk fat content ( $\mathrm{r}$ $=0.59 ; \mathrm{P}<0.0001$ ), contributed significantly to the decrease in milk fat. The effect of supplementation of diets with free vegetable oils on the milk content of de novo-synthesized FA is well documented in the literature (EIFERT et al., 2006b; ROY et al., 2006; SHINGFIELD et al., 2010; RIBEIRO et al., 2014). However, there are still no published results for diets based on fresh chopped sugarcane.

Another factor that may have contributed to the reduction in de novo FA synthesis in the mammary gland is lower plasma concentrations of the precursors acetate and $\beta$-hydroxybutyrate (SHINGFIELD et al., 2010; BERNARD et al., 2018) resulting from possible inhibition by SO of ruminal fermentation by fibrolytic microbiota of the fibrous carbohydrates present in the diet (RIBEIRO et al., 2018). According to Durand et al. (1988), the fermentation of citrus pulp mainly produces acetate. These authors reported that the molar proportions of acetate, propionate and butyrate were $0.625,0.261$ and 0.068 , respectively. The partial replacement of ground corn by citrus pulp in the present study did not alter the ruminal concentrations of acetate and butyrate in the animals that received the experimental treatments, as verified in the companion paper in which the ruminal metabolism of cows fed the same diets evaluated in the present study was examined (SOUZA, 2011). Thus, the concentrations of the precursors acetate and $\beta$-hydroxybutyrate may not have been primarily responsible for the reduction in de novo FA synthesis in the mammary gland.

Despite the absence of an effect on NDF digestibility $(\mathrm{P}=0.0576), \quad \mathrm{SO}$ supplementation promoted a linear reduction $(\mathrm{P}<0.001)$ in the milk content of odd- and branched-chain FA (OBCFA)
(Table 6). This may be considered indicative of the reduced activity and growth of bacterial communities in response to adaptive changes in the rumen environment of cows (VLAEMINCK et al., 2006). In addition, the substitution of NFC (citrus pulp and ground corn) by the EE present in SO already reduces the amount of fermentable substrate available for the ruminal microbiota (RODRIGUES et al., 2017), limiting its development. In corroboration of this, negative correlations were observed $(\mathrm{P}<0.0001)$ between milk OCBFA content versus EE intake ( $\mathrm{r}$ $=-0.73$ ) and between milk OCBFA content versus oleic, linoleic and $\alpha$-linolenic acid intake $(r=-0.64$ to -0.77$)$.

SO supplementation promoted an increase in ruminal $\mathrm{BH}$ that can be verified by several indications: the quadratic effect $(\mathrm{P}=0.0004)$ on milk stearic acid (C18:0) content (Table 6), the reduction $(\mathrm{P}<0.05)$ in the apparent transfer of consumed linoleic and $\alpha$-linolenic acids into milk (Table 7), and the linear increase $(\mathrm{P}<0.0001)$ in the milk content of trans-6 to trans-16 C18:1, cis-11 to cis-13 C18:1, and conjugated (e.g., rumenic, trans-10, cis-12 CLA, and trans-9, cis-11 CLA) and nonconjugated (cis-9, trans-12 C18:2) isomers of linoleic acid (Table 6). These FA, which are intermediate products of ruminal $\mathrm{BH}$ reactions of unsaturated FA (SHINGFIELD et al., 2010), showed a positive correlation $(\mathrm{P}<0.01)$ with the intake of oleic acid ( $\mathrm{r}$ $=0.49$ to 0.85$)$ and linoleic acid $(r=0.52$ to 0.85$)$ and, to a lesser extent, with that of $\alpha$-linolenic acid ( $r=0.44$ to 0.73 ). This can be explained by the low intake of $\alpha$-linolenic acid (Table 3). None of the ingredients used, including sugarcane, which accounted for $60 \%$ of diet DM, is an important source of $\alpha$-linolenic acid (Table 4). Mohammed et al. (2009) reported that $\sim 79 \%$ of the variability in the production of rumenic acid in bovine milk was explained by $\alpha$-linolenic acid intake. The correlation between milk rumenic acid content and linoleic acid intake $(\mathrm{r}=0.61, \mathrm{P}<0.0001)$ was higher than that calculated for $\alpha$-linolenic acid intake $(\mathrm{r}=$ $0.53, \mathrm{P}=0.0002$ ). A similar pattern was observed in 
the correlations with the milk content of vaccenic acid, the precursor for the endogenous synthesis of rumenic acid in the cow mammary gland. On one hand, this indicates that the higher intake of linoleic acid was the most relevant factor in the secretion of rumenic acid in milk; however, on the other hand, it was also the main factor responsible for the increased milk content of trans-10, cis-12 CLA ( $\mathrm{r}=0.64 ; \mathrm{P}<0.0001)$ and trans-9, cis-11 CLA $(\mathrm{r}=0.72 ; \mathrm{P}<0.0001)$. This indicates that the SO supplementation caused dysbiosis in the bacterial community of the rumen (ZENED et al., 2013).

Table 7. Apparent transfer of ingested fatty acids (FA, g day ${ }^{-1}$ ) into milk ( $\left.\mathrm{g}_{\text {day }}{ }^{-1}\right)$ from Holstein $\mathrm{x}$ Gyr cows fed sugarcane-based diets containing increasing levels of sunflower oil (SO).

\begin{tabular}{lccccccc}
\hline \multirow{2}{*}{ Apparent transfer } & \multicolumn{3}{c}{ SO levels (\% of diet DM) } & Standard error of & \multicolumn{2}{c}{ P-value } \\
\cline { 2 - 5 } \cline { 9 - 10 } & 0.0 & 1.5 & 3.0 & 4.5 & the mean & Linear & Quadratic \\
\hline cis-9 C18:1 & 1.271 & 0.818 & 0.557 & 0.554 & 0.0615 & $<0.0001$ & 0.0003 \\
cis-9, cis-12 C18:2 & 0.093 & 0.041 & 0.023 & 0.021 & 0.0035 & $<0.0001$ & $<0.0001$ \\
cis-9, cis-12, cis-15 C18:3 & 0.067 & 0.045 & 0.029 & 0.029 & 0.0043 & $<0.0001$ & 0.0068 \\
\hline
\end{tabular}

Due to the high contribution of linoleic acid to the rumen, especially in animals fed the $4.5 \%$ $\mathrm{SO}$ diet, the maximum capacity of ruminal $\mathrm{BH}$ of this FA via the formation of rumenic and vaccenic acids, which is performed mainly by Butyrivibrio fibrisolvens (McKAIN et al., 2010), may have been reached, triggering the need for the microbiota to perform ruminal $\mathrm{BH}$ through an alternative pathway (ZENED et al., 2013; RICO et al., 2015; PITTA et al., 2018). The quadratic effect $(\mathrm{P}=0.0004)$ observed in milk content of stearic acid (Table 6) indicates that the maximum capacity of ruminal $\mathrm{BH}$ of linoleic acid was reached; this occurred at 3.83\% SO. McKain et al. (2010) demonstrated in vitro that Propionibacterium acnes does not metabolize geometric isomers of CLA but is specialized in isomerizing linoleic acid to trans-10, cis-12 CLA. These authors also reported that $B$. fibrisolvens JW11 metabolized trans-10, cis-12 CLA to trans-10 C18:1, trans-12 C18:1, and cis-12 C18:1. Corroborating this, there were positive correlations $(\mathrm{P}<0.001)$ between the milk content of trans-10, cis12 CLA and the content of these monounsaturated isomers of $0.90,0.66$, and 0.35 , respectively.

The shift from the trans-11 to the trans-10 alternative $\mathrm{BH}$ pathway of linoleic acid is typical of diets supplemented with vegetable oils (JENKINS; HARVATINE, 2014; RIBEIRO et al., 2018). Comparing the control diet with the diet containing $4.5 \% \mathrm{SO}$, increases of $395 \%$ and $708 \%$ in the milk content of rumenic acid and trans-10, cis-12 CLA, respectively, were observed (Table 6 ), demonstrating that these two pathways of $\mathrm{BH}$ of linoleic acid were concomitantly performed by the ruminal microbiota. In addition, the absence of an effect $(\mathrm{P}>0.05)$ on the trans-11 C18:1/trans-10 C18:1 ratio (Table 6) shows that there was no prevalence of one ruminal $\mathrm{BH}$ pathway over the other. In the companion paper in which the ruminal metabolism of cows fed the same diets evaluated in the present study was examined, Souza (2011) reported that there was no effect of the experimental treatments on ruminal $\mathrm{pH}$; the mean $\mathrm{pH}$ values were higher than 6.0. The strategy of partially replacing ground corn with citrus pulp may have contributed in some way to these results, avoiding an even greater reduction in $\mathrm{pH}$ values with even more marked consequences on the shift from the trans-11 to the trans-10 alternative BH pathway of linoleic acid in the rumen.

It should be noted that trans-11 C18:1 and trans-10 C18:1 are the main trans-monounsaturated 
isomer intermediates of the ruminal $\mathrm{BH}$ pathways of linoleic acid (SHINGFIELD et al., 2010). Furthermore, assuming that the linear increase $(\mathrm{P}<0.0001)$ in milk content of trans-10, cis-12 CLA (Table 6) was a reflection of its concentration in the rumen, it is possible that this increase may also have contributed to the reduction in the Butyrivibrio proteoclasticus population. McKain et al. (2010) observed that the P-18 strain of B. proteoclasticus did not develop in medium containing trans-10, cis-12 CLA. According to these authors, B. proteoclasticus performs the final step of $\mathrm{BH}$, converting vaccenic acid and trans-10 C18:1 FA into stearic acid in the rumen. Therefore, reduction of its population in the rumen is related to the accumulation of trans-C18:1 FA at the expense of stearic acid. The observed reductions $(\mathrm{P}<0.05)$ in the stearic acid/vaccenic acid and stearic acid/trans-10 $\mathrm{C} 18: 1$ acid ratios in the milk of cows receiving SO (Table 6) can be considered indicative of adaptation of the ruminal microbiota.

In response to $\mathrm{SO}$ supplementation, there was a quadratic effect $(\mathrm{P}=0.0068)$ on the milk content of vaccenic acid and a pronounced linear increase $(\mathrm{P}<0.0001)$ in the milk content of trans-10 C18:1 acid as well as of most trans-C18:1 FA, including elaidic acid (Table 6). Comparing the $4.5 \%$ SO diet with the control diet, marked increases of $265 \%$, $563 \%$, and $1,433 \%$ in the milk content of elaidic, vaccenic, and trans-10 C18:1 acids, respectively, were observed (Table 6). Elaidic acid and trans-10 C18:1 acid have been associated with deleterious effects on cardiovascular health (ALMEIDA et al., 2014; VAHMANI et al., 2017); therefore, an increase in the levels of these FA in milk is not desirable for human nutrition. However, the content of elaidic and trans-10 C18:1 acids in milk obtained with the SO-supplemented diets (Table 6) in our study is within the range of values $(0.33$ to $0.73 \mathrm{~g} 100$

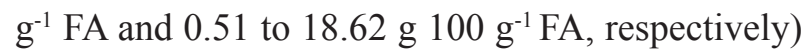

reported by Kliem and Shingfield (2016) in studies of the inclusion of vegetable oils in diets supplied to cows.

On the other hand, vaccenic acid, which is the major trans-C18:1 isomer (Table 6), is the precursor for the synthesis of $70 \%$ to $97 \%$ of rumenic acid in bovine milk (KLIEM; SHINGFIELD, 2016). Therefore, diets that promote an increase in the supply of vaccenic acid from the rumen to the mammary gland generally result in higher levels of rumenic acid in the milk; this is corroborated by the regression results for milk content (g $100 \mathrm{~g}^{-1} \mathrm{FA}$ ) of rumenic versus vaccenic acid $(\hat{\mathrm{y}}=0.37898 * \mathrm{x}$ $\left.+0.05805 ; \mathrm{r}^{2}=0.76 ; \quad \mathrm{P}<0.0001\right)$. However, comparison of the $4.5 \% \mathrm{SO}$ diet with the control diet shows that the $395 \%$ increase in the milk content of rumenic acid was disproportionately lower than the observed $563 \%$ increase in the milk content of vaccenic acid. This can be attributed to the linear decrease $(\mathrm{P}<0.0001)$ in stearoyl-CoA desaturase (SCD) enzyme activity in the rumenic acid/vaccenic acid pair (Table 8 ). In a study of bovine mammary epithelium, Kadegowda et al. (2009) reported that trans-10 C18:1 and trans-10, cis-12 CLA reduced SCD enzyme expression by $100 \%$ and $357 \%$, respectively. Subsequently, the observed high negative correlations $(\mathrm{P}<0.0001)$ between the SCD desaturase index for the rumenic acid/vaccenic acid pair versus the milk content of trans-10 C18:1 ( $\mathrm{r}=$ -0.66) and trans-10, cis-12 CLA $(\mathrm{r}=-0.60)$ indicate that these FA actually contributed to the inhibition of rumenic acid synthesis in the mammary gland. However, the milk content of rumenic acid obtained in response to SO supplementation (Table 6) was quite high compared to the range of 0.17-2.05 $\mathrm{g} 100$ $\mathrm{g}^{-1}$ FA reported for animals fed diets based on 57 $68 \%$ sugarcane with or without supplementation with lipid concentrates (MENESES et al., 2015; PIMENTEL et al., 2016). 
Table 8. Milk fat desaturase indexes from Holstein x Gyr cows fed sugarcane-based diets containing increasing levels of sunflower oil (SO).

\begin{tabular}{|c|c|c|c|c|c|c|c|}
\hline \multirow{2}{*}{ Desaturase index } & \multicolumn{4}{|c|}{ SO levels ( $\%$ of diet DM) } & \multirow{2}{*}{$\begin{array}{c}\text { Standard error of } \\
\text { the mean }\end{array}$} & \multicolumn{2}{|c|}{ P-value } \\
\hline & 0.0 & 1.5 & 3.0 & 4.5 & & Linear & Quadratic \\
\hline cis-9 C14:1/(C14:0 + cis-9 C14:1) & 0.084 & 0.071 & 0.065 & 0.067 & 0.0126 & 0.0006 & 0.0214 \\
\hline cis-9 C16:1/(C16:0 + cis-9 C16:1) & 0.044 & 0.038 & 0.036 & 0.040 & 0.0050 & 0.0553 & 0.0022 \\
\hline cis-9 C18:1/(C18:0 + cis-9 C18:1) & 0.651 & 0.604 & 0.602 & 0.602 & 0.0275 & 0.0011 & 0.0172 \\
\hline Rumenic/(Rumenic + Vaccenic) & 0.331 & 0.296 & 0.269 & 0.245 & 0.0306 & $<0.0001$ & 0.6036 \\
\hline
\end{tabular}

There were negative correlations between the SCD desaturase index for the oleic acid/stearic acid pair versus the milk content of trans-10 C18:1 ( $\mathrm{r}=$ $-0.36 ; \mathrm{P}=0.0168)$ and trans -10 , cis-12 CLA $(\mathrm{r}=-0.30$, $\mathrm{P}=0.0457)$, indicating that these FA also modulate the synthesis of oleic acid in the mammary gland. Esterification of oleic acid at the $s n-3$ position of triacylglycerol constitutes an important mechanism for controlling the melting point and fluidity of milk fat (SHINGFIELD et al., 2010).

SO supplementation improved the nutritional quality of milk fat, as shown by the linear decrease $(\mathrm{P}<0.0001)$ in $\mathrm{AI}$ and $\mathrm{TI}$ and the linear increase $(\mathrm{P}<0.0001)$ in the $\mathrm{h} / \mathrm{H}$ FA ratio (Table 9). This can be attributed mainly to the decrease in the milk content of hypercholesterolemic lauric, myristic and palmitic acids (FAO, 2010), the concomitant increase in oleic acid content, which is associated with beneficial effects on cardiovascular health (HAMMAD et al., 2016), and specifically to the reduction in TI, which is also due to an increase in the milk content of stearic acid (Table 6). Comparing the $4.5 \%$ SO ration with the control ration, the reductions $(\mathrm{P}<0.0001)$ in the milk content of lauric, myristic and palmitic acids were $57 \%$, $41 \%$ and $42 \%$, respectively, and the increase in milk content of oleic acid was 39\% (Table 6). However, SO supplementation promoted a linear increase $(\mathrm{P}=0.0055)$ in the $\omega-6 / \omega-3$ FA ratio (Table 9$)$.

Table 9. Indices of nutritional quality of milk fat in Holstein x Gyr cows fed sugarcane-based diets containing increasing levels of sunflower oil (SO).

\begin{tabular}{lcccccccc}
\hline \multicolumn{1}{c}{ Index $^{1}$} & \multicolumn{3}{c}{ SO levels $(\%$ of diet DM) } & Standard error of & \multicolumn{2}{c}{ P-value } \\
\cline { 1 - 1 } & 0.0 & 1.5 & 3.0 & 4.5 & & the mean & Linear & Quadratic \\
\hline AI & 5.37 & 3.62 & 2.75 & 2.25 & 0.2825 & $<0.0001$ & 0.0760 \\
TI & 6.37 & 4.74 & 3.94 & 3.50 & 0.3656 & $<0.0001$ & 0.0876 \\
h/H fatty acid ratio & 0.31 & 0.46 & 0.62 & 0.72 & 0.0495 & $<0.0001$ & 0.4891 \\
$\omega-6 / \omega-3$ fatty acid ratio & 16.4 & 19.2 & 19.3 & 20.8 & & 1.0266 & 0.0055 & 0.4947 \\
\hline
\end{tabular}

${ }^{1}$ Calculated according to Ribeiro et al. (2018): $\mathrm{AI}=$ atherogenicity index; $\mathrm{TI}=$ thrombogenicity index; h/H fatty acid ratio $=$ hypo/ hypercholesterolemic fatty acids ratio; $\omega-6 / \omega-3$ FA ratio = omega-6/omega-3 fatty acids ratio.

There was no effect $(\mathrm{P}>0.05)$ of $\mathrm{SO}$ supplementation on plasma glucose concentration (Table 10), as also observed by Rodrigues et al. (2017) in cows fed sugarcane-based diets supplemented with up to $7.34 \%$ soybean oil. In the companion paper, which studied the ruminal metabolism in cows fed the same diets evaluated in the present study, Souza (2011) observed no effect of the experimental treatments on the ruminal concentration of propionate (a glucogenic substrate), despite the partial substitution of the pectin of citrus pulp for the starch of ground corn. Thus, in the present study, the lack of effect of the treatments on glucose concentration (Table 10) may be, at least in part, a reflection of this. 
Table 10. Serum concentrations of metabolites in Holstein x Gyr cows fed sugarcane-based diets containing increasing levels of sunflower oil (SO).

\begin{tabular}{|c|c|c|c|c|c|c|c|}
\hline \multirow{2}{*}{ Item } & \multicolumn{4}{|c|}{ SO levels ( $\%$ of diet DM) } & \multirow{2}{*}{$\begin{array}{l}\text { Standard error of } \\
\text { the mean }\end{array}$} & \multicolumn{2}{|c|}{ P-value } \\
\hline & 0.0 & 1.5 & 3.0 & 4.5 & & Linear & Quadratic \\
\hline Glucose $\left(\mathrm{mg} \mathrm{dL}^{-1}\right)$ & 55.3 & 59.1 & 57.0 & 61.9 & 4.6665 & 0.1891 & 0.9108 \\
\hline Nonesterified fatty acids $\left(\mathrm{mmol} \mathrm{L}^{-1}\right)$ & 0.139 & 0.171 & 0.191 & 0.218 & 0.0249 & 0.0006 & 0.8454 \\
\hline Cholesterol $\left(\mathrm{mg} \mathrm{dL}^{-1}\right)$ & 86.0 & 115.4 & 122.4 & 145.6 & 13.3149 & $<0.0001$ & 0.5409 \\
\hline Triglycerides $\left(\mathrm{mg} \mathrm{dL}^{-1}\right)$ & 2.65 & 2.47 & 4.16 & 3.82 & 0.3738 & 0.0019 & 0.8167 \\
\hline
\end{tabular}

The linear increases $(\mathrm{P}<0.01)$ in the plasma concentrations of NEFA, cholesterol, and triglycerides (Table 10) were a consequence of increased lipid absorption in the gut and increased transport in the blood in response to increased SO intake.

\section{Conclusions}

The inclusion of up to $4.5 \%$ sunflower oil in $60 \%$ chopped sugarcane-based diets containing citrus pulp improved the nutritional quality of milk fat from Holstein x Gyr dairy cows as a result of the increased content of oleic, rumenic and vaccenic acids, which are beneficial to human health, and a concomitant reduction in the milk content of hypercholesterolemic lauric, myristic and palmitic acids. However, there was an increase in the milk content of trans-10 C18:1 and elaidic acid, which are associated with deleterious effects on cardiovascular health.

\section{Acknowledgments}

The authors gratefully acknowledge the Fundação de Amparo à Pesquisa de Minas Gerais (Fapemig), Conselho Nacional de Desenvolvimento Científico e Tecnológico (CNPq) and Embrapa Dairy Cattle for scholarships and for financial support of this study. We would also like to thank the technicians Ernando Ferreira Motta and Hernani Guilherme Barbosa Filho, who performed the analyses of fatty acid composition at the Laboratory of Chromatography of Embrapa Dairy Cattle.

\section{References}

ALMEIDA, M. M.; LUQUETTI, S. C. D.; SABARENSE, C. M.; CORRÊA, J. O. A.; REIS, L. G.; CONCEIÇÃO, E. P. S.; LISBOA, P. C.; MOURA, E. G.; GAMEIRO, J.; GAMA, M. A. S.; LOPES, F. C. F.; GONZÁLEZ GARCIA, R. M. Butter naturally enriched in cis-9 trans-11 CLA prevents hyperinsulinemia and increases both serum HDL cholesterol and triacylglycerol levels in rats. Lipids in Health and Disease, London, v. 13, n. 200, p. 1-13, 2014. DOI: 10.1186/1476-511X-13-200.

ASSIS, A. J.; CAMPOS, J. M. S.; VALADARES FILHO, S. C.; QUEIROZ, A. C.; LANA, R. P.; EUCLYDES, R. F.; MENDES NETO, J.; MAGALHÃES, A. L. R.; MENDONÇA, S. S. Polpa cítrica em dietas de vacas em lactação. 1. Consumo de nutrientes, produção e composição do leite. Revista Brasileira de Zootecnia, Viçosa, MG, v. 33, n. 1, p. 242-250, 2004. DOI: 10.1590/ S1516-35982004000100028

BAMPIDIS, V. A.; ROBINSON, P. H. Citrus by-products as ruminant feeds: a review. Animal Feed Science and Technology, Amsterdam, v. 128, n. 3, p. 175-217, 2006. DOI: $10.1016 /$ j.anifeedsci.2005.12.002

BERNARD, L.; BONNET, M.; DELAVAUD, C.; DELOSIÈRE, M.; FERLAY, A.; FOUGÈRE, H.; GRAULET, B. Milk fat globule in ruminant: major and minor compounds, nutritional regulation and differences among species. European Journal of Lipid Science and Technology, Weinheim, v. 120, n. 5, 1700039, 2018. DOI: 10.1002/ejlt.201700039.

CAMPOS, M. M.; LOPES, F. C. F.; PEREIRA, L. G. R.; MACHADO, F. S.; TOMICH, T. R. Cana-de-açúcar na alimentação de rebanhos leiteiros. In: SILVA, F. C.; ALVES, B. J. R.; FREITAS, P. L. (Ed.). Sistema de produção mecanizada da cana-de-açúcar integrada à produção de energia e alimentos. Brasília: EMBRAPA, 2017. v. 2, p. 900-938.

CARMO, C.A.; BATISTEL, F.; SOUZA, J.; MARTINEZ, J. C.; CORREA, P.; PEDROSO, A. M.; SANTOS, F. A. P. Starch levels on performance, milk composition and 
energy balance of lactating dairy cows. Tropical Animal Health and Production, Dordrecht, v. 47, n. 1, p. 179184, 2015. DOI: 10.1007/s11250-014-0704-4

DETMANN, E.; VALADARES FILHO, S. C.; BERCHIELLI, T. T.; CABRAL, L. S.; LADEIRA, M. M.; SOUZA, M. A.; QUEIROZ, A. C.; SALIBA, E. O. S.; PINA, D. P.; AZEVEDO, J. A. G. Métodos para análise de alimentos. Visconde do Rio Branco: Suprema, 2012. $214 \mathrm{p}$.

DURAND, M.; DUMAY, C.; BEAUMATIN, P.; MOREL, M. T. Use of the rumen simulation technique (Rusitec) to compare microbial digestion of various by-products. Animal Feed Science and Technology, Amsterdam, v. 21 , n. $2-4$, p. 197-204, 1988. DOI: 10.1016/03778401(88)90101-0

EIFERT, E. C.; LANA, R. P.; LANNA, D. P. D.; LEOPOLDINO, W. M.; OLIVEIRA, M. V. M.; ARCURI, P. B.; CAMPOS, J. M. S.; LEÃO, M. I.; VALADARES FILHO, S. C. Consumo, produção e composição do leite de vacas alimentadas com óleo de soja e diferentes fontes de carboidratos na dieta. Revista Brasileira de Zootecnia, Viçosa, MG, v. 35, n. 1, p. 211-218, 2006a. DOI: 10.1590/ S1516-35982006000100027

EIFERT, E. C.; LANA, R. P.; LANNA, D. P. D.; TEIXEIRA, R. M. A.; ARCURI, P. B.; LEÃO, M. I.; OLIVEIRA, M. V. M.; VALADARES FILHO, S. C. Perfil de ácidos graxos e conteúdo de ácido linoleico conjugado no leite de vacas alimentadas com a combinação de óleo de soja e fontes de carboidratos na dieta. Revista Brasileira de Zootecnia, Viçosa, MG, v. 35, n. 4, p. 18291837, 2006b. DOI: 10.1590/S1516-35982006000600034

FOOD AND AGRICULTURE ORGANIZATION OF THE UNITED NATIONS - FAO. Fats and fatty acids in human nutrition. Report of an expert consultation. Roma: FAO, 2010. 166 p.

HAMMAD, S.; PU, S.; JONES, P. J. Current evidence supporting the link between dietary fatty acids and cardiovascular disease. Lipids, Urbana, v. 51, n. 5, p. 507-517, 2016. DOI: 10.1007/s11745-015-4113-x

JENKINS, T. C. Lipid metabolism in the rumen. Journal of Dairy Science, Champaign, v. 76, n. 12, p. 3851-3863, 1993. DOI: $10.3168 /$ jds.S0022-0302(93)77727-9

JENKINS, T. C.; HARVATINE, K. J. Lipids feeding and milk fat depression. Veterinary Clinics: Food Animal Practice, Amsterdam, v. 30, n. 3, p. 623-642, 2014. DOI: 10.1016/j.cvfa.2014.07.006

KADEGOWDA, A. K. G.; BIONAZ, M.; PIPEROVA, L. S.; ERDMAN, R. A.; LOOR, J. J. Peroxisome proliferator-activated receptor- $\gamma$ activation and longchain fatty acids alter lipogenic gene networks in bovine mammary epithelial cells to various extents. Journal of Dairy Science, Champaign, v. 92, n. 9, p. 4276-4289, 2009. DOI: $10.3168 /$ jds.2008-1932

KLIEM, K. E.; SHINGFIELD, K. J. Manipulation of milk fatty acid composition in lactating cows: opportunities and challenges. European Journal of Lipid Science and Technology, Weinheim, v. 118, n. 11, p. 1661-1683, 2016. DOI: 10.1002/ejlt.201400543

LEITE, L. A.; REIS, R. R.; PIMENTEL, P. G.; SATURNINO, H. M.; COELHO, S. G.; MOREIRA, G. R. Performance of lactating dairy cows fed sunflower or corn silages and concentrate based on citrus pulp or ground corn. Revista Brasileira de Zootecnia, Viçosa, MG, v. 46, n. 1, p. 56-64, 2017. DOI: 10.1590/s180692902017000100009

LOPES, F. C. F.; SILVA, B. C. M.; ALMEIDA, M. M.; GAMA, M. A. S. Lácteos naturalmente enriquecidos com ácidos graxos benéficos à saúde. In: MARTINS, P. C.; PICCININI, G. A.; KRUG, E. E. B.; MARTINS, C. E.; LOPES, F. C. F. Sustentabilidade ambiental, social e econômica da cadeia produtiva do leite: desafios e perspectivas. Brasília: EMBRAPA, 2015. p. 237-309. Available at: https://ainfo.cnptia.embrapa. br/ digital/bitstream/item/128155/1/Cap-13-Lv-2015Sustentabilidade-Lacteos.pdf. Accessed at: 27 ago. 2018.

McKAIN, N.; SHINGFIELD, K. J.; WALLACE, R. J. Metabolism of conjugated linoleic acids and 18:1 fatty acids by ruminal bacteria: products and mechanisms. Microbiology, London, v. 156, n. 2, p. 579-588, 2010. DOI: $10.1099 / \mathrm{mic} .0 .036442-0$

MENESES, M. A.; SILVA, F. F.; SILVA, R. R.; SCHIO, A. R.; SILVA, G. M.; RODRIGUES, E. S. O.; PORTO JUNIOR, A. F.; SOUZA, D. D.; PONDE, W. P. S. T. S.; OLIVEIRA, J. S. O.; PIMENTEL, L. R. Composição em ácidos graxos do leite de vacas alimentadas com glicerina de baixa pureza. Semina: Ciências Agrárias, Londrina, v. 36, n. 2, p. 971-984, 2015. DOI: 10.5433/1679-0359.2015v36n2p971

MOHAMMED, R.; STANTON, C. S.; KENNELLY, J. J.; KRAMER, J. K. G.; MEE, J. F.; GLIMM, D. R.; O'DONOVAN, M.; MURPHY, J. J. Grazing cows are more efficient than zero-grazed and grass silage-fed cows in milk rumenic acid production. Journal of Dairy Science, Champaign, v. 92, n. 8, p. 3874-3893, 2009. DOI: $10.3168 /$ jds.2008-1613

NATIONAL RESEARCH COUNCIL - NRC. Nutrients requirements of dairy cattle. $7^{\text {th }} \mathrm{ed}$. Washington: National Academy Press, 2001. 381 p.

PIMENTEL, L. R.; SILVA, F. F.; SILVA, R. R.; RODRIGUES, E. S. O.; MENESES, M. A.; PORTO 
JUNIOR,A.F.; SOUZA, D.D.; SILVA, G. M.; PACHECO, C. C.; OLIVEIRA, P. A. Fatty acid profile of milk from cows fed palm kernel cake. Semina: Ciências Agrárias, Londrina, v. 37, n. 4, p. 2773-2784, 2016. Suplemento 1. DOI: $10.5433 / 1679-0359.2016 v 37 n 4 S u p 11 p 2773$

PITTA, D. W.; INDUGU, N.; VECCHIARELLI, B.; RICO, D. E.; HARVATINE, K. J. Alterations in ruminal bacterial populations at induction and recovery from diet-induced milk fat depression in dairy cows. Journal of Dairy Science, Champaign, v. 101, n. 1, p. 295-309, 2018. DOI: $10.3168 /$ jds.2016-12514

RIBEIRO, C. G. S.; LOPES, F. C. F.; GAMA, M. A. S.; MORENZ, M. J. F.; RODRIGUEZ, N. M. Desempenho produtivo e perfil de ácidos graxos do leite de vacas que receberam níveis crescentes de óleo de girassol em dietas à base de capim-elefante. Arquivo Brasileiro de Medicina Veterinária e Zootecnia, Belo Horizonte, v. 66, n. 5, p. 1513-1521, 2014. DOI: 10.1590/1678-6886

RIBEIRO, C. G. S.; LOPES, F. C. F.; GAMA, M. A. S.; RODRIGUEZ, N. M.; MORENZ, M. J. F. Ruminal fermentation and degradation, kinetic flow of the digesta and milk fatty acid composition of cows fed chopped elephant grass supplemented with soybean oil. Semina: Ciências Agrárias, Londrina, v. 39, n. 4, p. 1775-1794, 2018. DOI: $10.5433 / 1679-0359.2018 v 39 n 4 p 1775$

RICO, D. E.; PRESTON, S. H.; RISSER, J. M.; HARVATINE, K. J. Rapid changes in key ruminal microbial populations during the induction of and recovery from diet-induced milk fat depression in dairy cows. British Journal of Nutrition, Cambridge, v. 114, n. 3, p. 358-367, 2015. DOI: 10.1017/S0007114515001865

RODRIGUES, J. P. P.; PAULA, R. M.; RENNÓ, L. N.; FONTES, M. M. S.; MACHAD, A. F.; VALADARES FILHO, S. C.; HUHTANEN, P.; MARCONDES, M. I. Short-term effects of soybean oil supplementation on performance, digestion, and metabolism in dairy cows fed sugarcane-based diets. Journal of Dairy Science, Champaign, v. 100, n. 6, p. 4435-4447, 2017. DOI: 10.3168/jds.2016-11725

ROY, A.; FERLAY, A.; SHINGFIELD, K. J.; CHILLIARD, Y. Examination of the persistency of milk fatty acid composition responses to plant oils in cows given different basal diets, with particular emphasis on trans-C18:1 fatty acids and isomers of conjugated linoleic acid. Animal Science, Cambridge, v. 82, n. 4, p. 479-492, 2006. DOI: 10.1079/ASC200658
SHINGFIELD, K. J.; BERNARD, L.; LEROUX, C.; CHILliARD, Y. Role of trans fatty acids in the nutritional regulation of mammary lipogenesis in ruminants. Animal, Cambridge, v. 4, n. 7, p. 1140-1166, 2010. DOI: $10.1017 / \mathrm{S} 1751731110000510$

SOUZA, S. M. Desempenho e perfil de ácidos graxos do leite de vacas alimentadas com óleo de girassol em dietas à base de cana-de-açúcar. 2011. Tese (Doutorado em Zootecnia) - Universidade Federal de Viçosa, Viçosa, MG.

VAHMANI, P.; MEADUS, W. J.; DUFF, P.; ROLLAND, D. C.; DUGAN, M. E. R. Comparing the lipogenic and cholesterol genic effects of individual trans-18:1 isomers in liver cells. European Journal of Lipid Science and Technology, Weinheim, v. 119, n. 3, 1600162, 2017. DOI: $10.1002 /$ ejlt.201600162

VALADARES FILHO, S. C.; MACHADO, P. A. S.; CHIZZOTTI, M. L.; AMARAL, H. B.; MAGALHÃES, K. A.; ROCHA JÚNIOR, V. C.; CAPELLE, E. R. (Ed.). Tabelas brasileiras de composição de alimentos para bovinos. 3. ed. Viçosa, MG: UFV/DZO, 2010. 502 p.

VLAEMINCK, B.; FIEVEZ, V.; CABRITA, A. R. J.; FONSECA, A. J. M.; DEWHURST, R. J. Factors affecting odd- and branched-chain fatty acids in milk: A review. Animal Feed Science and Technology, Amsterdam, v. 131 , n. $3 / 4$, p. $389-417$, 2006. DOI: 10.1016/j.anifeedsci.2006.06.017

WEISS, W. P. Energy prediction equations for ruminant feeds. In: CORNELL NUTRITION CONFERENCE FOR FEED MANUFACTORERS, 61., 1999, Ithaca. Proceedings... Ithaca: Cornell University, 1999. p. 176185.

YANG, B.; CHEN, H.; STANTON, C.; ROSS, R. P.; ZHANG, H.; CHEN, Y. Q.; CHEN, W. Review of the roles of conjugated linoleic acid in health and disease. Journal of Functional Foods, Amsterdam, v. 15, May, p. 314-325, 2015. DOI: 10.1016/j.jff.2015.03.050

ZENED, A.; ENJALBERT, F.; NICOT, M. C.; TROEGELER-MEYNADIER, A. Starch plus sunflower oil addition to the diet of dry dairy cows results in a trans-11 to trans-10 shift of biohydrogenation. Journal of Dairy Science, Champaign, v. 96, n. 1, p. 451-459, 2013. DOI: $10.3168 /$ jds.2012-5690 
